\title{
Perubahan Format dan Desain Surat Kabar Indonesia dalam Perspektif "McJournalism"
}

\author{
Awang Ruswandi \\ ABSTRACT

\begin{abstract}
The changing of newspapers format and design in Indonesia become a prominence phenomenon in recent times. When Kompas, a national leading newspaper in Indonesia, changed its format and design, it was sufficiently enough to claim that McJournalism phenomenon started to appear in Indonesia. McJournalism, adopted by Bob Franklin from Ritzer's famous term

"McDonaldization," consisted of four characteristic: efficiency, calculability, predictability, and control. An analysis to such changes on some Indonesian major newspaper formats and designs have proven that the policy led also to the changing of mechanisms and working routines in those newspapers as well.
\end{abstract}

Kata kunci: McJournalism, format, tata letak, koran

Pertengahan tahun 2005, halaman-halaman surat kabar di Indonesia, atau lebih tepat di Jakarta, berubah wajah dan penampilannya. Perubahan format dan desain ini terjadi hampir serempak. Kini kita dapat menjumpai Kompas, Media Indonesia, Republika, Sinar Harapan, The Jakarta Post, dan sebagainya dengan format yang sama dan desain yang mirip.

Perubahan yang terjadi pada saat itu cukup fenomenal. Setelah harian Kompas mengubah format dan desain halamannya, maka beberapa harian lain yang terbit di Jakarta turut pula berubah. Kompas sendiri mengubah format (reformatting) dan desainnya (Redesigning) (Dhakidae, 2005) pada 28 Juni 2005 yang bertepatan dengan hari ulang tahun ke-40 harian ini. Harian yang turut mengubah format halamannya dalam waktu yang berdekatan dengan Kompas adalah Media Indonesia yang berubah pada 29 Juni 2005 dan Sinar Harapan, yang berganti format pada 19 Juli 2005 (Cakram Komunikasi, Agustus 2005: 22).
Perubahan yang dilakukan oleh redaksi surat kabar tersebut umumnya terjadi pada format halaman. Walaupun format desain halaman yang baru ini masih tetap broadsheet, namun ukurannya mengecil dari 42 X $58 \mathrm{~cm}$ menjadi 38 X $57,5 \mathrm{~cm}$ (contoh ukuran halaman Kompas), atau jumlah kolomnya berkurang dari sembilan kolom menjadi tujuh kolom.

Kompas sendiri sebenarnya tidak hanya mengubah format halaman. Namun, konsep desain halaman secara keseluruhannya juga berubah. Ukuran kertas, struktur halaman, jenis dan besar huruf, tata wajah, cara penulisan, dan warna logo (name plate, pen) turut berubah pula (Cakram Komunikasi, Agustus 2005: 22). Menurut Cakram Komunikasi, hal lainnya yang berubah adalah struktur halaman dibagi menjadi empat seksi yang terdiri dari beberapa rubrik.

Menurut Mario R. Garcia, CEO Gracia Media - perusahaan konsultasi desain surat kabar yang meredesain Kompas, wajah ini tidak cuma masalah 
perubahan jenis huruf dan warna belaka. Wajah ini melibatkan sebuah reorganisasi isi yang menyeluruh, tambahan-tambahan topik baru, serta sebuah tampilan sebuah navigasi yang membuat para pembaca dapat bergerak ke seluruh surat kabar secara lebih cepat (Garcia, 2005).

Sementara itu, pada Media Indonesia, seperti dituturkan Alexander Stephanus--Pemimpin Perusahaan Media Indonesia, perubahan tersebut dilakukan untuk untuk merespon tren media cetak dunia ke arah yang lebih kecil (Cakram Komunikasi, Agustus 2005:22).

Menurut majalah Cakram Komunikasi, sesungguhnya perubahan format surat kabar ini sudah dimulai oleh Jawa Pos pada 1997 dan diikuti oleh surat kabar-surat kabar yang berada di bawah naungan kelompok usaha Jawa Pos Group. Menurut Dahlan Iksan, Direktur Jawa Pos Group, keinginan kuat perubahan itu muncul ketika dirinya sering ke AS antara 1984-1994. Ketika itu di AS tengah terjadi gelombang perubahan ukuran koran dari 9 kolom menjadi 7 kolom (Cakram Komunikasi, Agustus 2005:21).

Sementara itu, Koran Tempo mengubah formatnya dari broadsheet menjadi tabloid (compact) pada akhir Mei 2005. Majalah Cakram Komunikasi memberikan penilaian terhadap perubahan Koran Tempo sebagai berikut: untuk sebuah harian serius, format yang diusung Koran Tempo tampak sangat beda. Ragam kreasi dan tampilan sebuah koran muncul seiring dengan perubahan ini (Cakram Komunikasi, Agustus 2005:21).

Perubahan demi perubahan yang dilakukan oleh para pengelola surat kabar tersebut terus bergulir. Gelombang perubahan yang sangat terasa terutama setelah Kompas berubah. Artinya, dalam waktu yang berdekatan, banyak surat kabar mengubah formatnya mengikuti jejak Kompas. Mereka berbondongbondong mengecilkan format surat kabarnya dengan jumlah kolom dari sembilan menjadi tujuh.

\section{"McJournalism" yang Bersumber dari "McDonaldization"}

Adanya tren perubahan format dan desain halaman surat kabar ini dapat dilihat dari sudut pandang atau pendekatan dengan menggunakan konsep McJournalism dari Bob Franklin yang mengadopsinya dari konsep McDonaldisasi (McDonaldization) dari George Ritzer (Franklin, 2005). McDonaldisasi sendiri adalah konsep yang diperkenalkan Ritzer dengan mengambil filosofi pengelolaan restoran cepat saji McDonald (Ritzer, 1996).

Restoran McDonald telah menjadi model dan merasuk segala aspek kehidupan masyarakat Amerika Serikat dan masyarakat di berbagai belahan dunia lainnya. Industri-industri lain telah mencontoh sukses McDonald dalam memproduksi dan memasarkan barangnya. Bahkan banyak kalangan mencantumkan merek $M c$ dalam merek dagang mereka, seperti "McChild" sebagai tempat perawatan anak, "McStables" untuk tempat pelatihan pacuan kuda. Hal tersebut juga terjadi dalam industri surat kabar dengan munculnya istilah "McPaper" untuk surat kabar USA TODAY yang diperkenalkan oleh Peter Prichard (Ritzer, 1996: 7). Sementara artikel-artikel pendek yang diterbitkannya dikenal sebagai "News McNuggets". Ketika USA TODAY memuat acara televisi, beberapa kalangan menyebutnya sebagai "News McRather" (lihat Franklin 2003)

Keberhasilan USA TODAY di pasaran bisnis surat kabar Amerika Serikat pada gilirannya juga diikuti oleh surat kabar-surat kabar lainnya. Hal yang ditirunya, antara lain, cara penulisan yang pendek dan pembuatan ramalan cuaca yang berwarna (Ritzer, 1996: 7). Jadi, fenomena ini mirip dengan apa yang dialami McDonald sendiri yang ditiru dalam semua sepak terjangnya.

Contoh paling nyata pengaruh USA TODAY ini dapat dilihat dalam surat kabar The Boca Raton News yang dijuluki surat kabar Knight-Rider. Surat kabar ini digambarkan sebagai a short smorgasboard of snippets, surat kabar yang mengiris dan memotong berita bahkan menjadi lebih kecil daripada yang dibuat USA TODAY, menambahinya dengan grafis berwarna dan faktafakta (kejadian) yang lucu serta feature-feature yang mungil seperti "Today's Hero" dan "Critter Watch" (Ritzer, 1996: 8).

Ritzer juga menggambarkan bahwa artikel- 
artikel yang dimuat The Boca Raton News sama seperti di USA TODAY, biasanya tidak bersambung dari satu halaman ke halaman lainnya. Artikel-artikel tersebut dimulai dan diakhiri pada halaman yang sama. Untuk memenuhi tuntutan seperti itu, ceritacerita yang kompleks (panjang) seringkali harus dipotong dan dijadikan paragraf-paragraf pendek. Konsekuensi dari tindakan tersebut, banyak konteks cerita dan banyak hal prinsip yang seharusnya diungkapkan terpaksa dipotong atau dihilangkan sama sekali. Dengan penekanan pada berita yang ringan dan grafis berwarna, fungsi utama surat kabar yang menonjol adalah hiburan. Bahkan The New York Times telah mengalami perubahan (contohnya penggunaan warna) sebagai hasil dari keberhasilan USA TODAY (Ritzer, 1996: 8).

Konsep McDonaldisasi memiliki empat dimensi, yaitu efficiency, calculability, predictability, dan control. Efisiensi berarti memilih alat yang optimal untuk sebuah hasil yang diberikan (Ritzer, 1996: 35). Pengalkulasian (calculability) menekankan pada sesuatu yang dapat dikalkulasi, dihitung, dan diukur (Ritzer, 1996: 59), lebih mendahulukan kuantitas daripada kualitas. Dimensi tentang hal yang dapat diramalkan (predictability) melibatkan penekanan terhadap sesuatu seperti disiplin, sistematisasi, dan kerutinan sehingga segala sesuatunya sama dari satu waktu ke waktu yang lain dan dari satu tempat ke tempat yang lain. Predictability diperoleh melalui berbagai cara, termasuk replikasi dari pengaturan, penggunaan script untuk mengontrol apa yang pegawai harus katakan, perutinan perilaku pegawai, dan penawaran produk-produk yang seragam (Ritzer, 1996: 99). Dimensi kontrol lebih melihat adanya penggantian manusia oleh teknologi bukan manusia. Hal itu disebabkan karena sumber ketidakpastian, sesuatu yang tidak dapat diramalkan, dan sesuatu yang tidak efisien di dalam sistem yang rasional adalah manusia. Dalam McDonaldisasi, pengontrolan tersebut terjadi baik di kalangan pegawai maupun konsumen (Ritzer, 1996: 101).

Dengan mengadopsi konsep McDonaldisasi, Bob Franklin, seorang profesor dari Department of Journalism Studies, University of Sheffield, Inggris mengembangkan konsep McJournalism (Franklin, 2005). Menurut Franklin, dalam derajat tertentu tesis McDonaldization dengan penekanan pada efficiency, calculability, predictability, dan kontrol, membantu menjelaskan perkembangan jurnalisme saat ini dan menjelaskan munculnya apa yang disebut McJournalism (Franklin: www.psa.ac.uk/cpas/2003\%5Cbob\%20 Franklin.pdf).

Dalam dimensi efisiensi, Franklin merujuk kepada contoh-contoh yang diberikan Ritzer tentang penyajian artikel-artikel di USA TODAY yang bisa selesai dalam satu halaman dan tidak ada halaman bersambung. Hal itu dianggap sebagai efisiensi dalam kegiatan jurnalisme. Oleh karena itu, surat kabar yang dianggap serius seperti New York Times dan Washington Post dianggap tidak efisien untuk dibaca, karena menyajikan artikel-artikel yang bersambung dari satu halaman ke halaman lain (Ritzer, 1996: 49).

Ritzer secara panjang lebar menjelaskan bagaimana soal efesiensi yang dilakukan surat kabar dan majalah dalam menyajikan artikelnya.

This was accomplished by ruthlessly editing stories to dramatically simplify and reduce narrative content (no word wasted), leaving a series of relatively bare facts. In this, USA TODAY was anticipated by the various digests, most notably the still popular Reader's Digest. The original aim of Reader's Digest was to offer magazine articles that "could be written to please the reader, to give him the nub of the matter in the new fast-moving world of the 1920s, instead of being written at length and with literary embellishments to please the author or the editor." Other precursors to USA TODAY are magazines such as Time, Newsweek, and Business Week. The simplified character of the latter compared with the Wall Street Journal was stressed by two observers: "The messages is that busy executives don't have time to read in depth so don't waste time reading the Wall Street Journal every day when one quick bite of Business Week once a week is sufficient to give you a step ahead of the competition (Ritzer, 1996: 49).

Oleh karena itu, menurut Franklin, surat kabar harus membuat berita yang dapat diakses dengan mudah oleh para pembaca. Akibatnya, surat kabar 
menggunakan judul-judul yang besar, kata-kata yang pendek, judul-judul yang jenaka, judul-judul yang sensasional, cerita pendek, gambar-gambar berwarna, dan banyak lagi. Franklin memberikan contoh secara terperinci tentang hal ini:

Newspapers increasingly offer readers "News at a Glance" which provides a précis of the day's in a vertical column down the left or right hand side of the page: on the left hand column of the inside page, the Guardian offers readers the "Two-Minute Guardian". For "Busy People With Busy Lives" Guardian journalists thoughtfully provide The Editor, a small, glossy, colourful distillation of the week's news, along with book and film reviews which can be read at a glance (Franklin, 2003).

Untuk dimensi pengalkulasian, Franklin merujuk kepada kasus penambahan jumlah halaman surat kabar yang terus berlangsung. Penambahan ini juga terjadi pada surat kabar-surat kabar Inggris yang menurut Franklin terus tumbuh sejak tahun 1980-an.

Pagination has also expanded since the mid 1980s: and prolifically. Between 1984 and 1994, the Sunday Times grew from 178 pages to 362 , while the Sunday Express (32 to 184), the Mail on Sunday (64 to 220), the Sunday Mirror (48 to 120) the Daily Express (36 to 64) and The Times (32 to 72) all increased in size substantially. Similar to the ambition of Big Macs, British newspapers are - in the words of the advertising slogan - "Bigger than ever, with more news than ever". Like Big Macs, few claims are made for quality (Franklin, 2003).

USA TODAY masih merupakan contoh kasus menarik tentang pentingnya kuantitas dibanding kualitas seperti diungkapkan Ritzer.

Instead of detailed stories, USA TODAY offers many short, easily and quickly read stories. It is the kind of newspaper than can be read in about the time it takes a person to consume a meal at a fast-food restaurant (Ritzer, 1996: 76).

Franklin melihat dimensi predictability dalam surat kabar-surat kabar Inggris melalui adanya keseragaman tampilan dan agenda isi. Keseragaman agenda berita itu terjadi untuk beritaberita olah raga, selebriti, kriminal, dan bahkan masalah-masalah politik.
Occasionally the similarity of news agendas is striking. On the day that the

Beckham's second child was born, for example, the two biggest selling competitor tabloids carried a (literally) predictable, indeed, identical headline "Romeo, Romeo, Why For Art Thou Romeo?" (Sun and Mirror September 2002). On 10 April 2003, the British press reported the collapse of military opposition to coalition forces in Baghdad with a mind-numbingly uniform set of front pages. The Mail, Sun, Express, Mirror, Guardian, Telegraph, Independent and The Times, with minimum variation, carried the same picture of a statue of Saddam Hussein being pulled to the ground by a chain attached to a military vehicle (doubtless provided by the same picture agency), captioned with the Subs' punny word play "Toppled" or "The Toppling of Saddam” (Franklin, 2003).

Pengontrolan melalui teknologi baru telah memberikan efek terhadap pekerjaan jurnalisme. Franklin mencatat, perkembangan teknologi yang paling mutakhir telah pula memberikan implikasi yang radikal terhadap jurnalisme.

The availability of high powered laptop computers, equipped with modems no bigger than a credit card, mobile telephones, and digital cameras mean that pictures and reports of events can - and must - be filed within seconds. Speed, accuracy and efficiency are the obvious benefits of such technology as a 1000 word story can be filed in seconds without the need of a copy taker (typist). The drawbacks of such technology are probably more evident to the copy takers than newspaper managers. But new technology also isolates journalists, makes them individuals rather than team workers, cuts them off from the collective news room culture, encourages and facilitates freelance work, reduces journalists bargaining power, encourages multiskilling practices and empowers managers against journalists and other production workers (Franklin, 2003).

\section{Perubahan Desain dalam "McJournalism"}

Konsep McJournalism dapat dipakai untuk menelaah tren perubahan format dan desain surat kabar yang terjadi pada pertengahan 2005 ini. Walaupun yang dilihat bukan proses jurnalisme 
surat kabar secara keseluruhan, tetapi konsep tersebut masih dapat dipakai untuk pisau analisis. Desain halaman surat kabar, bagaimana pun, tidak dapat dipisahkan dari rangkaian proses jurnalisme. Ia adalah terminal akhir dari hasil proses jurnalisme. Desain halaman surat kabar merupakan salah satu variabel yang dapat mempengaruhi proses jurnalismenya itu sendiri. Sebagai contoh, adanya perbedaan cara penyajian artikel bersambung dari satu halaman ke halaman lain dengan artikel tanpa sambungan mempengaruhi bagaimana cara para reporter dan editor menulis berita.

Seperti sudah disinggung di atas, bahwa Kompas telah menjadi trend setter bagi perubahan desain halaman surat kabar broadsheet di Jakarta. Sebagian besar surat kabar berbondong-bondong mengikuti jejak Kompas untuk mengubah format dan desain halaman surat kabar mereka. Gejala ini dapat dianalogikan dengan fenomena banyak kalangan menggunakan kata $M c$ untuk merek dagang produk ataupun jasa tertentu yang mengikuti jejak McDonald karena restoran cepat saji ini telah terkenal dan berhasil meraup banyak keuntungan dan gerainya berada di berbagai pelosok bumi. Begitu pula dengan Kompas, karena Kompas adalah market leader surat kabar di Indonesia (Hidayat, 2005), maka banyak surat kabar lain meniru gaya dan penampilan Kompas.

Ketika Kompas mengubah format dan desain, maka surat kabar lain pun ikut berubah. Pada saat itulah Kompas telah menjadi trend setter. Hal itu berbeda dengan kasus perubahan desain halaman Jawa Pos dan Koran Tempo. Ketika Jawa Pos berubah penampilan, yang mengikuti jejaknya hanyalah surat-surat kabar yang berada dalam kelompok jaringan usaha Jawa Pos. Hal itu tidak fenomenal, karena mereka masih berada dalam satu payung perusahaan. Begitu juga dengan Koran Tempo, ketika surat kabar ini berubah format dari broadsheet menjadi tabloid, bisa dikatakan tidak ada surat kabar lain yang menirunya.

Gejala ini juga mirip dengan apa yang terjadi dengan McPaper. Kompas layaknya USA Today. Penampilannya ditiru, gayanya diikuti. Dan, sesungguhnya dengan desain yang sekarang dipakainya, Kompas sendiri juga bisa dikatakan mengikuti jejak USA Today. Namun, barangkali ada satu yang tidak sama, yaitu Kompas masih suka menyajikan artikel halaman satu bersambung ke halaman lain.

Dilihat dari dimensi-dimensi McDonaldisasi, dengan format dan desain baru tersebut, maka soal efisiensi menjadi salah satu variabelnya. Untuk Kompas saja, dengan desain yang baru ini, tampak jelas bahwa sekarang Kompas banyak menampilkan artikel-artikel pendek termasuk di halaman satu. Padahal, sebelumnya, Kompas jarang memasang artikel pendek, apalagi di halaman pertama. Dalam menyajikan beritanya, selama ini Kompas dikenal menyajikan tulisan yang panjang dan mendalam. Seiring perubahan ini, cara penulisan lebih pendek, ringkas, dan padat dibanding dengan tulisan-tulisan sebelumnya (Cakram Komunikasi, Agustus 2005: 22).

Munculnya tren perubahan format dan desain di sejumlah surat kabar, sesungguhnya berkaitan pula dengan format iklannya. Jika surat kabar non Kompas tidak mengikuti format halaman Kompas, maka format sebuah iklan yang sama yang dimuat di Kompas tidak akan pas dipasang (tidak kompatibel), terutama jika iklan tersebut berukuran setengah atau satu halaman. Jika hal ini terjadi, maka surat kabar non Kompas bisa tidak kebagian iklan.

Tidak akan ada biro iklan yang mau membuat dua format berbeda dari iklan satu produk tertentu untuk ditempatkan dalam media sejenis, sebab hal itu tidak efisien. Demi efisiensi dan mengejar efektivitas, maka biro iklan tentu hanya akan membuat satu format iklan dan akan memasangnya di surat kabar yang jumlah oplahnya paling banyak seperti Kompas. Seandainya pun iklan tersebut harus dipasang di surat kabar lain karena pertimbangan tertentu, maka iklan dengan format dan desain yang sama dengan yang dipasang, di Kompas lah yang akan dipasangnya.

Jika surat kabar non-Kompas tidak mengubah format, maka akan terjadi dua hal. Pertama, surat kabar tersebut akan memasang format iklan yang tidak kompatibel yang akibatnya akan memperburuk desain halaman iklan dan pada akhirnya akan merusak citra surat kabar yang 
bersangkutan. Kedua, tidak kebagian iklan, jika surat kabar tersebut bersikukuh bahwa iklan yang dimuatnya harus kompatibel dengan format halaman yang dimilikinya. Oleh karena itu, barangkali para pengelola surat kabar itu berpikiran lebih baik ikut berubah mengikuti sang market leader daripada tidak kebagian iklan.

Korelasi antara perubahan format surat kabar dengan iklan ini dinyatakan secara eksplist oleh pengelola Media Indonesia. Menurut Pemimpin Perusahaan Media Indonesia, perubahan ini disambut positif oleh para pemasang iklan karena desain iklan lebih fleksibel serta meningkatkan opportunity to see iklan (Cakram Komunikasi, Agustus 2005: 22).

Soal mempertimbangkan perubahan format halaman surat kabar dan kehadiran iklan ini juga dapat dilihat dari dimensi calculability. Dengan mengubah format dan mengharapkan iklan masuk, itu artinya juga membuat kalkulasi pendapatan yang akan diperoleh surat kabar. Kehadiran iklan dalam surat kabar adalah penting untuk menopang hidup surat kabar yang bersangkutan. Iklan menurut istilah para pengelola surat kabar — adalah pemberi subsidi bagi pembaca. Kata mereka, surat kabar akan mahal harganya jika tidak ada iklan.

Dimensi calculability juga menyoroti kecenderungan gejala mementingkan kuantitas daripada kualitas. Hal itu dapat dilihat dari makin bertambahnya jumlah halaman surat kabar. Kompas misalnya, biasanya terbit dengan 40 halaman dalam keadaan normal. Namun, sering pula Kompas terbit dengan 64 halaman. Dengan semakin bertambahnya halaman, pembaca merasakannya makin banyak iklan yang dijumpai dibandingkan dengan isi editorial non-iklan (walaupun hal ini perlu dibuktikan dengan penelitian). Bahkan Kompas membuat satu seksi tersendiri, yaitu "Klasika" sebagai tempat bercokolnya iklan baris dan iklan kolom. Seksi "Klasika" dirasakan pembaca sebagai suplemen yang tak perlu dibaca, kehadirannya ibarat junkfood.

Dari sisi predictability, adanya kecenderungan perubahan format ini memperjelas adanya standardisasi format. Jadi, dari aspek format halaman saja, surat kabar-surat kabar tersebut seragam. Begitu juga desain dan tata letak halamannya. Sekarang ini hampir semua surat kabar membagi halamannya berdasarkan seksi-seksi. Foto semuanya berwarna. Navigasi-navigasi yang ada di setiap halaman Kompas dapat dijumpai pula di Media Indonesia, Koran Tempo, Seputar Indonesia, dan sebagainya.

Melalui dimensi kontrol, terlihat bahwa perubahan format dan desain surat kabar ini terkait dengan adanya kemajuan teknologi. Perubahan desain adalah sebuah keniscayaan karena adanya perkembangan teknologi yang sangat pesat. Perkembangan teknologi yang tidak secara langsung bersentuhan dengan desain surat kabar pun memiliki implikasi juga terhadap desain. Salah satu contohnya adalah adanya teknologi internet. Menurut Garcia, secara tidak sadar para pembaca modern surat kabar mengalihkan kebiasaan quick browsing internet ke dalam cara mereka membaca (Garcia, 2005).

Kepala Litbang Kompas, Daniel Dhakidae, juga mengakui bahwa perkembangan teknologi di luar surat kabar memiliki imbas terhadap perkembangan surat kabar.

Surat kabar generasi modern industrial bersaing dengan televisi tentang seberapa cepat menyajikan kejutan berita yang disebut scoop. Surat kabar generasi postmodern harus bersaing dengan bukan sekedar dengan televisi, tetapi televisi yang sudah mengalami “transformasi" oleh seluruh teknologi digital yang memungkinkan multimedia, dengan internet sebagai pusatnya, di mana setiap orang bisa serentak mendengar, melihat, membaca sesuatu yang berasal dari aneka sumber pada saat yang hampir bersamaan (Dhakidae, 2005).

\section{Penutup}

Perubahan format dan desain surat kabar memang tuntutan zaman. Adanya perubahan pola konsumsi dan gaya hidup pembaca merupakan salah satu faktor yang memengaruhi perubahan tersebut, di samping faktor-faktor lain, seperti perkembangan teknologi cetak, desain, dan sebagainya. 
Desain halaman surat kabar merupakan etalase dari produk jurnalisme. Bagaimanapun format dan desain halaman surat kabar akan memengaruhi proses jurnalismenya itu sendiri. Tulisan yang dibuat oleh para jurnalis tentu akan disesuaikan dengan konsep desain dan format surat kabarnya. Dedy N. Hidayat menengarai kecenderungan tersebut, kebijakan resizing, contohnya mendorong penyajian isi yang serba ringkas, berpotensi mengurangi kedalaman. Resizing sering kali juga membatasi ruang gerak individual para jurnalis untuk mengekspresikan potensi kepakaran mereka. Analisis yang mereka sajikan cenderung menjadi sekedar "berita tentang pendapat pakar" (Hidayat, 2005).

Adanya fenomena jurnalisme seperti itu merupakan imbas dari merasuknya ideologi McDonald ke dalam kegiatan jurnalisme. Karyakarya jurnalisme disajikan bak hidangan cepat saji ala McDonald. Oleh karena itu Bob Franklin menyebutnya sebagai McJournalism.

McJournalism is less concerned with a quality product than predictability and standardisation. McJournalism undermines the diversity which market theorists claim will emerge as a consequence of competition. McJournalism offers a dull, consistent, staple diet of programming which is obsessed with quantitative measures of "quality" such as ratings: McJournalism delivers the journalistic equivalent of Big Macs but is less concerned about Quality Macs (Franklin, 2003).

Gejala ini semakin masifmanakala banyak surat kabar menciptakan gelombang perubahan format dan desain surat kabar yang mirip satu sama lainnya. Fenomena ini ibarat gerai McDonald yang menyerbu pelosok negeri, dan di mana pun kita berada dapat menemukan gerai Mcdonald yang seragam dan standar. Sama halnya dengan McJournalism, ke mana pun pembaca pergi, ia akan menemukan surat kabar yang seragam dan standar dalam penampilan dan gayanya. Menurut Franklin, McJournalism increasingly produces newspapers with similar contents and on occasion identical headlines, lead stories and pictures provided by the same picture or news agency. McJournalism delivers the same flavourless mush (Franklin, 2003).

\section{Referensi}

Cakram Komunikasi. Edisi Agustus 2005.

Dhakidae, Daniel. 2005. “Kompas 2005: Mengapa Berubah?" dalam Kompas, 28 Juni.

Franklin, Bob. 2005. "McJournalism. The Local Press and the McDonaldization Thesis" dalam Stuart Allan (ed). Journalism: Critical Issues. London: Open University Press.

Franklin, Bob. 2003. "McJournalism”: The McDonaldization Thesis and Junk Journalism dalam www.psa.ac.uk/cpas/ 2003\%5Cbob\%20 Franklin.pdf

Garcia, Mario R. 2005. "Desain untuk Pembaca Era Digital” dalam Kompas, 28 Juni.

Hidayat, Dedy N. 2005. “Kompas Mencari Kompas" dalam Kompas, 29 Juni 2005.

Ritzer, George. 1996. The McDonaldization of Society. Rivised Edition. London: Pine Forge Press. 
